\title{
Does a Destination have Personality? Personality and Image Issues of a Destination
}

\author{
By Yasin Bilim* \\ Mebrure Boydemir Bilim ${ }^{\dagger}$
}

\begin{abstract}
Brand is a perceptual instrument and each affective value of the product (tourism destination) reflects the brand's impact on customer. Despite the importance of brand image in terms of marketing, much ambiguity rise in relation to its relationship with brand personality. While branding issues of goods and services are well examined in marketing studies, the application of branding techniques to places, especially to tourism destinations are still new. The purpose of this study is to explain the effects of the destination personality on destination image, and to fullfil the gap in the tourism literature about destination personality concept. This study, on the other hand, was developed for a particular destination to describe the destination's personality factors related to destination brand image. The study was hold in Didim as a growing destination in Turkey. The questionnaire was processed with simple descriptive analysis (frequency), simple correlation analysis and one-way ANOVA test. Consequently, three important destination personality elements (conviviality dimension) were defined and this three elements' relationships with all cognitive image elements and two affective image elements were significant. Also, these elements had some statistical significant differences with some sociodemographic factors.
\end{abstract}

\section{Introduction}

Brand is a perceptual instrument and each affective value of the product (tourism destination) reflects the brand's impact on customer. To examine the customer attitudes, brand can associate or possesses each attribute or emotional factor (Cohen, Fishbein \& Athola 1972). Brand builds an awareness set while unawareness set encompasses all brands that the buyer is unaware (Sirakaya \& Woodside 2005; Henderson, Cote, Leong \& Schmitt 2003). Brand is more than a name given to product; it embodies a whole set of physical and socio pyschological attributes and beliefs (Simoes \& Dibb 2001). A strong brand will distinguish a product or service from its competitors by reducing search cost, minimizing perceived risks, providing customer loyalty and positive word of

*Assistant Professor, Necmettin Erbakan University, Turkey.

†Lecturer, Selçuk University, Turkey.

https://doi.org/10.30958/ajt.1-2-2

doi $=10.30958 /$ ajt.1-2-2 
mouth, charging premium prices, leading to greater product trial and representing high quality from a consumer's point of view (Hosany, Ekinci \& Uysal 2006; Deslandes 2003). Thus, many companies are trying to get target customers' attention by creating distinctive brand image for their products (Kim, Han \& Park 2001). In marketing terms, brand and its image represent a promise of value. Brands have social, emotional and identity value to customers and stimulate beliefs, evoke emotions and prompt behaviours. Brands have personality and extend the perceived utility, desirability and quality of a product or service (Morgan, Pritchard \& Piggot 2003).

Individuals will accept with images similar to their perceived self concept and don't accept with images that are not similar. Brands, therefore, have a personality that users value beyond functional utility and consumers will use brands as a symbolic devices to explain and express their own particular personality (Diamantopoulos, Smith \& Grime 2005). Despite the importance of brand image in terms of marketing, much ambiguity rise in relation to its relationship with brand personality. Brand management researchers argue that brand image is a way for brands to differentiate their products. It also decreases search cost, perceived risks and represents high quality (Hosany et al. 2006). In recent years, there has been increased attention in brand personality construct as its strategic importance has become clearer (Diamantopoulos et al. 2005). While brand image can be defined as "perceptions about a brand as reflected by the brand associations held in the consumer's mind (Cai 2002; Keller 1993), brand personality is "the set of human characteristics associated to a brand" (Aaker 1997; 347; Aaker 1995; 1). However, brand image and personality are considered to share several defining elements. Both are consumer perceptions that result from consumers decoding, extracting and interpreting brand signals and associations and both can be affected by nearly everything related to brand (Hayes 1999; Aaker 1997).

Plummer (1985) implies by supporting this thesis that brand image consisted of three vital features; physical attributes (color, etc.), functional characteristics (cleans teeth more effectively) and characterization (e.g. youthful). The characterization process is based on brand personality and related to the human characteristics. This feature is well known that the introduction of brand extensions can have positive or negative affects on a core brand image and subsequent equity. With the key factor separating both being that brand personality consists of human characteristics associated with a brand, while brand image includes non-human elements such as physical components, price perceptions or manufacturer reputation (Hayes 1999). At the theoretical level, brand image has been defined in terms of brand personality (Hosany et al. 2006) and in some cases brand image is a much broader concept encompassing the attributes, benefits and consequences related to brand with personality concept (Wysong, Munch \& Kleiser 2002; Hayes 1999). So, despite their similarities, brand image and brand personality concepts are different. Not surprisingly, this differentiation has recently affected the marketing developments and marketers attempt to distinguish and rebuild preference for their brands not only on the basis of consumer perception about 
destination image, on the basis of these brand personality perception as well. It is believed that consumers prefer those brands to satisfy their functional needs and wants, also look for their personality reflections that they want to find most congruent with their own actual or desired components (Batra, Lenk \& Wedel 2006).

Branding issues of goods and services are well examined in marketing studies. But, application of branding techniques to places, especially to tourism destinations are not enough (Hosany et al. 2006; Cai 2002). Destination branding developments and academic inspections in the area are just in infancy period. On the other hand, studies on destination image are abundant and be traced back to early (Morgan et al. 2003; Cai 2002). However, between destination brand image and personality concepts relationship that have rooted brand personality issue, has examined more recently in tourism and there are few researches on this issue (Hosany et al. 2006). Consequently, the main purpose of this study is to explain the effects of the destination personality on destination brand image, and to fullfil the gap in the tourism literature about destination personality concept. Previous studies have used the destination personality concept for comparing the destinations. This study, on the other hand, was developed for a particular destination to describe the destination's personality factors related to destination brand image. This approach would be a key indicator for tourism marketers to develop new destination matketing strategies, and market segmentation policies.

\section{Destination Brand Image and Personality}

The growing importance of tourism in most countries has led to an increasing interest in studying the factors that effect tourists' perception destination and eventually, their buying behaviour. In addition, the globalization and the greater competition among the destinations has forced many countries to seek new ideas and approaches to maintain and extend visitor level. Destination branding is a such approach that has attracted the attention of destination managers and academics (Deslandes 2003). The destination branding literature also focuses on primarily on leisure tourism activities. There has been fe academic research about the places as a totaly tourism product (Hankinson 2005). Destination branding can be defined as "selecting a consistent element mix to identify and distinguish it through positive image building" (Cai 2002: 722). Destination branding provides destinations to develop a consistent brand identity (what the brand standarts for), which can be used to attract and maintain visitors (Deslandes 2003). For typical goods and services, the name is the first and foremost referance. However, the name of a destination brand is relatively fixed by actual geographical name of the place. Destination name plays a strategic role for developing destination brand identity and image (Cai 2002).

There is a common understanding in marketing literature that the brand is more than a name given to a product; it emcompasses a total set of physical 
and socio - psychological attributes and beliefs (Simoes \& Dibb 2001). These attributes can be related to image and personality factors. A brand is bound to person's image. Any change on this image is very difficult because brand users associate particular ideas about product or service personality. The personality factors are affected by strong emotional motivation to choose. As a result, consumer's personality traits to a product or service will be another emotional factor influencing inconsistency with brand personality (Ha 1998). Brands have personality and extend the perceived utility, desirability and quality of a product. When consumers make brand choices about product or service including destinations - they are building lifestyle statements since consumers are buying not only into an image but also into an emotional relationship (Morgan et al. 2003).

Here, the image of a destination can be taken as a product for individuals in the purchase process (Eclipse 2003; Kim \& Richardson 2003). Tourists are aroused by many images of destinations and these influence their attitudes and behaviours (White 2004). Since image is a mental process associated with tourist behaviour and perception, it plays an important role in the success of tourist destination (Beerli \& Martin 2004). Consequence of this evaluation, destination image can defined as the sum of beliefs, ideas, expectation, feelings and impressions that an individual has of a place or destination, and they also adapt its "emotional, personal, prejudice and imagination" aspects from others (White 2004; Kar \& Litvin 2003; Jenkins 1999; Baloğlu \& Brinberg 1997). Destination images are not only critical factor for potential tourists' decision making but also the level of satisfaction regarding the tourist experiences (White 2004; Jenkins 1999; Baloğlu \& McCleary 1999; MacKay \& Fesenmaier 1997). Leisen (2001: 50) briefly explains that, "the image represents the destination in the traveler's mind and gives him / her a pre-taste of that destination; it determines the traveler's consideration of a given area as a vacation destiniton. Then, once the destination is in the evoked set, its image is modified by further information and evaluated against the images of alternative destinations". The challenge for destination marketer is to promote the destinastion brand image live, so that visitors experience the promoted brand values, personality, image and feel the authenticity of a unique place (Morgan et al. 2003). In terms of destination branding, destination brand image can be defined as perception about place as reflected by relations held in tourists' mind (Cai 2002). Destination brands create sets of images of a place prior to consumption like product and service brands. Evidence suggests that visitors' preferences about destinations are focused on the degree to which they generate respective images. The more favourable images of a destination, the greater selection chance. Therefore a destination brand image is important and neccessery for its marketing effectiveness (Hankinson 2004; Leisen 2001; D'Hauteserre 2001). Destination branding is selecting a consistent mix of brand elements to describe and differentiate a destination through positive image building. A brand image is not a brand but a source of its value and of great inportance for destination image (Prebensen 2006). 
As a tourism product a destination has also a personality and like another typical products destination image attributes can also produce destination personality attributes. One component of destination image is the personality or character of the destination itself (Hankinson 2005). Hosany et al. (2006) have explored that destination image and destination personality are related concepts. Their survey results indicate that some of the destination image scales were signicantly related to the destination personality scales. They have adapted this study to Aaker's (1997) brand personality study and brand personality scale that have issued different product categories and various consumer brands, to explain destination brand image and destination personality concept about tourism destination. Moreover, Hosany et al. define the destination personality concept as (p.2) "the sets of human characteristics associated to a tourism destination". Morgan et al. (2003) additionally argues that brand differentiates products and provide a selection value to users by inciting beliefs, evoking emotions and induce behoviour. Including tourism destination, brands have personality and enhance the perceived utility, desirability and quality of product. Considering this construct, tourists evaluate the destination not only into an image view but also into a emotional and personal relationship and their personality traits (Morgan et al. 2003; Ha 1998). Personality is a component of image formation process. Concisely, it can be suggest that destination image and destination personality are related concepts and both concepts are neccessery for supporting destination loyalty, competitive advantage and consumer positive preferences (Hosany et al. 2006; Leisen 2001; Kim, Han \& Park 2001).

The creation of destination brands and related developments has been greatly assisted and accelareted by a number of commercial and political improvements in recent years (Hall 2004). Through these developments, place branding applications have been influential for not only countries, regions and cities, but also lower down the spatial scale places such as shopping destinations and leisure parks (Hankinson 2005). In general, while there has been the lack of attention paid to tourism destination branding as a country, region and city, recently branding has been accumulate a considerable time now because of its economic and marketing power (Gnoth 2002). According to this study's perspective, Turkey's image as a tourism destination briefly shoud be evaluated to reflect the image variations. Except the tourism and textile industry, image and brand studies about Turkey are very limited. Özmen (2004) suggests that some original Turkish products effect and develop the Turkey's overall brand image perception (her study is generally related to textile products). But, Güneş (2006) gives some informations about country brand image, based on an international marketing organization's report. According to this reports, Turkey's brand image is the last position on the list among thirty five countries (include Estonia, Indonesia). It is thought that Turkey has not a well-known image and some negative events have caused the undesired reflections. State Planning Organization (SPO) of Turkey (2000) explains the causes of these negative conditions as; Turkey has not a good 
image because of mainly historical problems with some countries and commercially negative propagandas of competitors.

In terms of tourism destination image formation, there is more attention about Turkey image as a tourism destination than other products' brand images. Based on an international survey, U.S. travel agents describe that Turkey mostly is a fascinating, exciting, stimulating, exotic, colorful, attractive, historic, ancient ruins, archeology, old and relatively memorable, magnificent, beautiful, majestic, magical, mysterious, mystic, intriguing, friendly, inviting people, hospitable destination. The study also points out that Turkey's main strength appears to be a "good value" destination that would be emphasized in communication strategy, provided that the destination improves its perception in terms of infrastructure, cleanliness, and entertainment (Baloğlu \& Mangaloğlu 2001). Baloğlu (1997) tends to correlate the image of Turkey with tourists' familarity. The study results indicate that the higher familiarity that tourists' feel, the more positive perception is saved about Turkey's image. Both high and medium familiarity groups perceived Turkey with more positive in terms of offering attractions, value/environment and pleasant and exciting destination than low familiarity group. The high familiarity group perceived Turkey as a more relaxing destination than medium and low familiarity groups. On the other hand, medium and high familiarity groups evaluated Turkey as more exciting than the low familiarity group. World Travel \& Tourism Council (2003) has pressed Turkey reports to show position of Turkey in World tourism market. And council postulates that although Turkey has traditionally focused on the mass sun and sea market, her incomparable diversity of natural resources and climate zones offers considerable potential for the development of new tourism products to meet growing demand for adventure tourism, eco-tourism and tailor-made cultural holidays.

Reviwing the tourism literature, it has been found a few study about destination image of Turkey. However, there is not any study about destination personality of Turkey and also any research that explain the effect of destination personality on destinaiton image with a survey results. The research has conducted in Didim/Aydin as the case because Didim is a new developing destination and the tourism potential of the city is very suitable for the new development steps. And, Didim is under new constructions for tourism developments, so, the new marketing strategies that will shape the future sustainable and well - planned developments are needed.

\section{Methodolgy}

To measure the destination personality effetcs and related issue about destination image, a questionnaire form was developed. Questionnaire content was shaped by previous related destination image and destination personality studies and the scales were selected from this studies. In the study there are different scales that was used to measure destination's affective and cognitive 
image, physical atmosphere and environment perception and destination personality. Additionally, the characteristics of the holiday were measured by some questions (duration of holiday, frequency of visitation, goals of holiday) and demographic factors were put into first part of form. Affective and cognitive image scales were stemed from Baloğlu and Mangaloğlu's (2001) destination image study. Affective image scale was schemed as semantic differantial (unpleasent - pleasent, sleepy - arousing, disstressing - relaxing, gloomy - exciting) and 12 cognitive image elements were rated as 5 - point Likert scale (1: strongly disagree - 5: strongly agree). For physical atmosphere (4 items) and environmental (4 items) elements which constructed as semantic differential was cited from Hosany's et al (2006) destination personality study and also in the study destination personality scale which adopted from Aaker's (1997) brand personality scale was used. In Aaker's study, there are five dimensions (big five: sincerity, excitement, competence, sophistication and ruggedness) related to brand with sub - dimensional elements, but Hosany et al. use three dimensions (sincerity, excitement, conviviality - mix of other three dimensions) for destination personality scale as five point Likert scale (1: not at all descriptive -5 : extremely descriptive).

Totaly 400 questionnaires were applied to foreign tourists and 312 valid forms were collected. The forms were processed by computer based program (SPSS 13.0) and the results were evaluated by statistical analysis. Descriptive analysis (frequency), simple correlation analaysis and one - way ANOVA analysis were run.

\section{Findings}

Firstly, the scales's reliability tests were calculated to provide the reliable conclusions. Four different scales were applied to reliability test and the reliability of the scales were generally high (except physical athmosphere and environment). Cronbach's Alpha ranges were as fallow: affective image scale (4 items): 0,829; physical athmosphere and environment scale: 0,695; cognitive image scale: 0,893; and destination personality scale: 0.948 .

Demographic factors of the participants are summarized in Table 1. The majority participants are old $(51$ - more $)$, female, british and graduated from high school. Some holiday characteristics, satisfaction perception and plannings for future of participant were asked. According to the answers, participants have been in Turkey generally more than 5 times $(39.3 \%)$ and 2-3 times $(36.2 \%)$ and in Didim generally first time (36.1\%), more than 5 times (32.1\%) and 2-3 times (23.6\%); have visited only Didim (57.1\%) and other destination in Turkey (42.9\%); have been staying in Didim for 1-2 weeks $(39,7 \%)$ and more than 5 months $(24.3 \%)$; are very satisfied with their holiday in Didim (71.3\%); are very likely to come back to Didim $(73.5 \%)$; are very likely to recommend their friends/relatives for holiday $(74.8 \%)$ and Didim could meet their holiday expectation entirely (74.9\%agree and strongly agree). It can be said that generally the perceptions of participants about satisfaction, 
future planning, recommendation and expectation related to Didim are very positive. But, participants visitation characteristics are very polarized, because some participants are retired and living in Didim (as resident) or staying very long in a year. But, this indicator can be usefull to find out orginal imaginal views and a more real consequences.

Table 1. Demographic Factors

\begin{tabular}{|c|c|c|c|c|c|}
\hline age & $\mathrm{n}$ & $\%$ & nationality & $\mathrm{n}$ & $\%$ \\
\hline $18-25$ & 41 & 13.4 & British & 277 & 88.9 \\
\hline $26-30$ & 27 & 8.8 & Scottish & 20 & 6.4 \\
\hline $31-35$ & 24 & 7.8 & Irish & 9 & 2.9 \\
\hline $36-40$ & 36 & 11.8 & German & 4 & 1.3 \\
\hline $41-45$ & 25 & 8.2 & Brazilian & 2 & 0.6 \\
\hline $46-50$ & 18 & 5.9 & education & $\mathrm{n}$ & $\%$ \\
\hline $51-$-more & 135 & 44.1 & primary & 2 & 0.9 \\
\hline gender & $\mathrm{n}$ & $\%$ & secondary & 62 & 26.7 \\
\hline male & 117 & 38.4 & high school & 127 & 54.7 \\
\hline female & 188 & 61.6 & under-graduate & 9 & 3.9 \\
\hline & & & graduate & 32 & 13.8 \\
\hline
\end{tabular}

The perceptial / cognitive and affective evaluations of a destination made by tourists have more impacts on descriptive outputs which can shape the destination brand and personality perceptions. Table 2 shows participants' affective evaluations, physical atmosphere and environmental perceptions about Didim. According to the answers, Didim generally is affected as a pleasent and relaxing and perceived as a friendly, easly accessible and interesting city by tourists. But, physical atmosphere of Didim has not positive and attractive elements for tourists, hovewer has not negative perceptions, generally neutral perceptions. Table 3 reflects the participants cognitive images perceptions. Tourists generally have the positive perception about cognitive image of Didim. Good climate, great beaches and water sports, interesting historical attractions and beatiful scenery and naturel attractions have more positive perception. It can be suggested that naturel and cultural cognitive elements of Didim are very attractive for tourists, with other elements and these attractions must have more attentions for marketing strategies, esspecially creating a new destination brand image and personality. 
Table 2. Affective Components, Physical Atmosphere and Environmental Reflections (\%)

\begin{tabular}{|c|c|c|c|c|c|c|c|}
\hline affective comp. & $\mathbf{1}$ & $\mathbf{2}$ & $\mathbf{3}$ & $\mathbf{4}$ & $\mathbf{5}$ & & mean \\
\hline unpleasent & 1.8 & 1.8 & 9.2 & 23.9 & 63.2 & pleasent & 4.44 \\
\hline sleepy & 1.3 & 5.2 & 29.4 & 25.1 & 39.6 & arousing & 3.95 \\
\hline disstressing & 2.7 & 2.1 & 10.3 & 21.0 & 63.9 & relaxing & 4.41 \\
\hline gloomy & 2.9 & 5.8 & 18.8. & 28.8 & 43.8 & excitimg & 4.04 \\
\hline physical atm. & & & & & & & \\
\hline noisy & 19.6 & 26.9 & 41.3 & 5.2 & 7.0 & quite & 2.53 \\
\hline sinful & 13.2 & 27.7 & 37.9 & 15.7 & 5.5 & innocent & 2.72 \\
\hline sleepy & 4.7 & 5.6 & 50.4 & 20.3 & 19.0 & arousing & 3.43 \\
\hline overcrowded & 4.0 & 6.6 & 63.7 & 16.4 & 9.3 & sparse & 3.20 \\
\hline environment & & & & & & & \\
\hline stagnant & 9.0 & 11.0 & 30.2 & 21.2 & 28.6 & lively & 3.49 \\
\hline cold & 10.2 & 11.7 & 12.8 & 11.3 & 54.0 & friendly & 3.87 \\
\hline isolated & 6.5 & 8.5 & 26.6 & 15.3 & 43.1 & easly accessible & 3.80 \\
\hline boring & 6.8 & 6.0 & 30.9 & 18.1 & 38.2 & interesting & 3.74 \\
\hline
\end{tabular}

Table 3. Cognitive Image (\%)

\begin{tabular}{|c|c|c|c|c|c|c|}
\hline items & 1 & 2 & 3 & 4 & 5 & mean \\
\hline good value for money & 7.1 & 5.7 & 21.6 & 24.0 & 41.6 & 3.87 \\
\hline beatiful scenery and naturel attractions & 2.1 & 5.2 & 13.5 & 27.4 & 52.7 & 4.21 \\
\hline good climate & 3.4 & - & 1.4 & 27.9 & 77.2 & 4.65 \\
\hline interesting cultural attractions & 3.5 & 4.6 & 14.8 & 28.2 & 48.9 & 4.14 \\
\hline suitable accomodations & 2.1 & 7.4 & 23.9 & 30.3 & 36.3 & 3.91 \\
\hline appealing local foods & 3.1 & 3.4 & 20.4 & 24.8 & 48.3 & 4.11 \\
\hline great beaches and water sports & 2.5 & 3.2 & 11.9 & 20.0 & 62.5 & 4.36 \\
\hline quality of infrastructure & 6.0 & 12.0 & 40.1 & 20.4 & 21.5 & 3.39 \\
\hline interesting historical attractions & 2.9 & 1.8 & 21.1 & 18.6 & 55.7 & 4.22 \\
\hline unpoluted and unspoiled environment & 5.2 & 11.8 & 31.1 & 23.9 & 28.0 & 3.57 \\
\hline good nigtlife and entertainment & 5.2 & 2.7 & 19.9 & 34.4 & 37.5 & 4.02 \\
\hline standart hygiene and cleanliness & 4.8 & 11.6 & 23.5 & 29.7 & 30.4 & 3.69 \\
\hline
\end{tabular}

1: strongly disagree -5 : strongly agree

The personality dimensions of this research was originated from Hosany et al. (2006) and they defined three dimensions of destination personality as sincerity, excitement and conviviality. In this study, realibility test results (sincerity: 0.92, excitement: 0.89, conviviality: 0.76) is higher than Hosany's et al. study (sincerity: 0.81, excitement: 0.72, conviviality: 0.69). The frequency results indicates that the conviviality dimension (friendly, family oriented, charming) more rated than other dimensions and shows Didim's personality perception as a tourism destination. 
Table 4. Destination Personality Perceptions (\%)

\begin{tabular}{|l|l|l|l|l|l|l|}
\hline items & 1 & 2 & 3 & 4 & 5 & mean \\
\hline sincere & 7.2 & 8.6 & 30.6 & 25.2 & 28.4 & 3.58 \\
\hline intelligent & 4.0 & 9.1 & 43.3 & 24.5 & 19.0 & 3.45 \\
\hline reliable & 7.2 & 6.1 & 33.8 & 25.9 & 27.0 & 3.59 \\
\hline succesfull & 1.5 & 8.6 & 42.9 & 22.0 & 25.0 & 3.60 \\
\hline secure & 6.3 & 10.7 & 32.5 & 24.7 & 25.8 & 3.53 \\
\hline wholesome & 3.0 & 6.6 & 39.5 & 28.8 & 22.1 & 3.60 \\
\hline down-to-earth & 7.3 & 5.1 & 23.0 & 28.5 & 36.1 & 3.81 \\
\hline exciting & 3.3 & 10.7 & 24.6 & 33.5 & 27.9 & 3.72 \\
\hline original & 8.8 & 8.3 & 34.8 & 25.7 & 23.2 & 3.47 \\
\hline unique & 8.8 & 7.4 & 33.5 & 27.9 & 22.4 & 3.47 \\
\hline spirited & 6.3 & 6.3 & 26.4 & 29.7 & 31.2 & 3.73 \\
\hline friendly & $\mathbf{5 . 1}$ & $\mathbf{1 . 0}$ & $\mathbf{1 0 . 8}$ & $\mathbf{2 1 . 6}$ & $\mathbf{6 1 . 5}$ & $\mathbf{4 . 3 3}$ \\
\hline family oriented & $\mathbf{5 . 4}$ & $\mathbf{2 . 2}$ & $\mathbf{1 5 . 5}$ & $\mathbf{2 0 . 9}$ & $\mathbf{5 6 . 0}$ & $\mathbf{4 . 1 9}$ \\
\hline charming & $\mathbf{1 . 8}$ & $\mathbf{3 . 5}$ & $\mathbf{2 1 . 4}$ & $\mathbf{3 1 . 1}$ & $\mathbf{4 1 . 8}$ & $\mathbf{4 . 0 4}$ \\
\hline
\end{tabular}

1: not at all descriptive -5 : extremely descriptive

Table 5, 6, 7 were structured to explain the relationships of destinaiton personality, image formations and holiday characteristics. Correlation analysis was run. Variables were correlated by Spearsman's corelation coefficient value. Three destination personality elements (friendly, family oriented, charming: conviviality dimensions) that have the highest value are determined for the correlation. The results of this analysis are as fallow; the majority of cognitive image components have high, very significant and positive correlations with three destination personality elements, especially "charming" has the highest value for destination personality. In Table 6, as it can be seen, the "pleasent" and "relaxing" variables effect three personality elements positively and "arousing" and "exciting" variables don't have the high value on destination personality. According to destination personality and holiday characteristics correlation, personality variables have the positive correlations with satisfaction, future plans for haliday in Didim and meeting expectations, especially "charming" and "expectation" variables have the highest corelation value. But, being in didim before and duration of holiday variables are negative correlation with two personality factors. It means that the more visiting and more staying in Didim for holiday, the less positive perception on friendly and charming personality factors. However, three personality factors haven't any important correlation with physical atmosphere and environmental perceptions. 
Table 5. Correlation Matrix (destination personality - cognitive image perception)

\begin{tabular}{|c|c|c|c|c|c|c|c|}
\hline & & $\begin{array}{l}\text { good } \\
\text { value } \\
\text { for } \\
\text { money }\end{array}$ & $\begin{array}{c}\text { beatiful } \\
\text { scenery and } \\
\text { naturel } \\
\text { attractions }\end{array}$ & $\begin{array}{l}\text { good } \\
\text { climate }\end{array}$ & $\begin{array}{l}\text { interesting } \\
\text { cultural } \\
\text { attractions }\end{array}$ & $\begin{array}{c}\text { suitable } \\
\text { accomodation }\end{array}$ & $\begin{array}{c}\text { appealing } \\
\text { local food } \\
\text { (cuisine) }\end{array}$ \\
\hline \multirow{2}{*}{ friendly } & $\mathrm{r}$ & .335 & .276 & .335 & .332 & .324 & .276 \\
\hline & $\mathrm{p}$ & .000 & .000 & .000 & .000 & .000 & .000 \\
\hline \multirow{2}{*}{$\begin{array}{c}\text { family } \\
\text { oriented }\end{array}$} & $\mathrm{r}$ & .233 & .175 & .340 & .302 & .305 & .338 \\
\hline & $\mathrm{p}$ & .000 & .004 & .000 & .000 & .000 & .000 \\
\hline \multirow{3}{*}{ charming } & $\mathrm{r}$ & .442 & .392 & .342 & .300 & .474 & .416 \\
\hline & $\mathrm{p}$ & .000 & .000 & .000 & .000 & .000 & .000 \\
\hline & & $\begin{array}{c}\text { great } \\
\text { beaches } \\
\text { and } \\
\text { water } \\
\text { sports }\end{array}$ & $\begin{array}{c}\text { quality of } \\
\text { infrastructure }\end{array}$ & $\begin{array}{l}\text { interesting } \\
\text { historical } \\
\text { attractions }\end{array}$ & $\begin{array}{c}\text { unpolluted } \\
\text { unspoiled } \\
\text { environment }\end{array}$ & $\begin{array}{l}\text { good nigtlife } \\
\quad \text { and } \\
\text { entertainment }\end{array}$ & $\begin{array}{l}\text { standart } \\
\text { hygiene } \\
\text { and } \\
\text { cleanliness }\end{array}$ \\
\hline \multirow{2}{*}{ friendly } & $\mathrm{r}$ & .191 & .293 & .298 & .354 & .445 & .413 \\
\hline & $\mathrm{p}$ & .001 & .000 & .000 & .000 & .000 & .001 \\
\hline \multirow{2}{*}{$\begin{array}{c}\text { family } \\
\text { oriented }\end{array}$} & $\mathrm{r}$ & .192 & .260 & .342 & .244 & .327 & .399 \\
\hline & $\mathrm{p}$ & .002 & .000 & .000 & .000 & .000 & .000 \\
\hline \multirow{2}{*}{ charming } & $\mathrm{r}$ & .335 & .497 & .305 & .427 & .518 & .519 \\
\hline & $\mathrm{p}$ & .000 & .000 & .000 & .000 & .000 & .000 \\
\hline
\end{tabular}

Table 6. Correlation Matrix (destination personality - affective image perception)

\begin{tabular}{|c|c|c|c|c|c|}
\hline & & pleasent & arousing & relaxing & exciting \\
\hline \multirow{2}{*}{ friendly } & $\mathrm{r}$ & .265 & - & .293 & - \\
& $\mathrm{p}$ & .000 & - & .000 & - \\
\hline family & $\mathrm{r}$ & .242 & - & .336 & - \\
oriented & $\mathrm{p}$ & .000 & & .000 & .284 \\
\hline \multirow{2}{*}{ charming } & $\mathrm{r}$ & .343 & .304 & .325 & .000 \\
& $\mathrm{p}$ & .000 & .000 & .000 & .000 \\
\hline
\end{tabular}

Table 7. Corrrelation Matrix (destination personality - holiday characteristics)

\begin{tabular}{|c|c|c|c|c|c|c|}
\hline & & $\begin{array}{c}\text { being in } \\
\text { Didim } \\
\text { before }\end{array}$ & $\begin{array}{c}\text { duration of } \\
\text { holiday }\end{array}$ & satisfaction & $\begin{array}{c}\text { future } \\
\text { plans for } \\
\text { holiday in } \\
\text { Didim }\end{array}$ & $\begin{array}{c}\text { meeting } \\
\text { expectations }\end{array}$ \\
\hline \multirow{2}{*}{ friendly } & $\mathrm{r}$ & -.157 & -.301 & .157 & - & .282 \\
& $\mathrm{p}$ & .008 & .000 & .010 & & .000 \\
\hline family & $\mathrm{r}$ & - & - & .223 & .147 & .338 \\
oriented & $\mathrm{p}$ & & -.000 & .024 & .000 \\
\hline charming & $\mathrm{r}$ & -.214 & -.263 & .346 & .266 & .482 \\
& $\mathrm{p}$ & .000 & .000 & .000 & .000 & .000 \\
\hline
\end{tabular}

The possible sociodemographic characteristics on the three important destination personality factors was analyzed using t-test and ANOVA. The results of t-tests on gender variables was not statistically significant. The other demographic factors (age, nationality and education) and destination personality relationship was hold in Table 8 . The significant indicators are as fallow: 18-25 years old tourists have negative differences with nearly all age 
groups related to "family" element, so young tourists' motivations and personality perceptions are not focused on family oriented factors; with respect to the relationship between education and destination personality, only "charming" variable has the significant indicator; and related to nationality factor, there are significant differences among British, German and Irish people, also between Scottish an German people. It is reasoned from the culturel based national perceptions about family.

Table 8. One-way ANOVA test with Demographic Factors (age, education, nation)

\begin{tabular}{|c|c|c|c|c|}
\hline age & & & mean differences & sig. \\
\hline family & $18-25$ & $31-35$ & -1.14 & .002 \\
\hline & & $36-40$ & -.88 & .009 \\
\hline & & $41-45$ & -.90 & .027 \\
\hline & & $46-50$ & -1.01 & .029 \\
\hline & & $51-$-more & -.80 & .001 \\
\hline education & & & mean differences & sig. \\
\hline charming & high school & graduate & .57 & .019 \\
\hline nationality & & & mean differences & sig. \\
\hline family & british & german & 2.79 & .000 \\
\hline & & 1rish & 1.07 & .027 \\
\hline & scottish & german & 2.35 & .001 \\
\hline
\end{tabular}

\section{Implications and Conclusions}

As it is mentioned by Hosany et al. (2006), destination image and destination personality are related concepts. Their survey results indicate that some of the destination image scales were signicantly related to the destination personality scales. This study also show the same results point out the same important points. Generally, destination image concept have got great attention, but recently destination personality issues gets the more attention especially related to image formation and perception. In terms of marketing, destination personality issue can be important factors for shaping future planning considerations and market segmentations and getting marketing goals. This study provides necessary informations for this goals. The results can be summerized as:

1. There is a significant relationship between destination image and personality. The personality factors effect the image perceptions and related factors. Conviviality dimension of destination personality is more significant than other dimensions on destination image perception for Didim.

2. All cognitive image elements are affected by personality factors and there is a significant relationship between both concept. Particularly, friendly and family oriented variables can be destination personality object and branding element towards a positive destination image. 
3. Didim is an attractive place for families and older people and so it can be evaluated as a marketing strategy.

4. Marketers also must take care about this strategy, because some sociodemographic differences can effect the tourists' perception.

5. This study can be an example for destination marketers. The study also shows the importance of the destination personality factors on tourists perceptions and decision making behaviour.

\section{References}

Aaker, J. L. (1995), Brand Personality: Conceptualization, Measurement and Underlying Physocological Mechanisms, Submitted Doctoral Dissertation, Stanford University.

Aaker, J. L. (1997), "Dimensions of brand personality", Journal of Marketing Research, vol: 34 (August 1997): 347-356.

Baloğlu, S. \& Brinberg, D. (1997), "Affective images of tourism destinations", Journal of Travel Research, 35 (4): 11-15.

Baloğlu, Ş. \& McCleary, K. W. (1999), "U.S. international pleasure travellers' image of four Mediterranean destinations: A comparison of visitors and nonvisitors", Journal of Travel Research, 38: 144-152.

Baloğlu, Ş. \& Mangaloğlu, M. (2001), "Touris destination images of Turkey, Egypt, Greece, and Italy as perceived by US - based operators and travel agents", Tourism Management, 22: 1 - 9 .

Baloğlu, Ş. (1997), "The relationship between destination images and sociodemographic and trip characteristics of international travelers", Journal of Vacation Marketing, 3 (3): 221 - 233.

Batra, R., Lenk, P. \& Wedel, M. (2006), "Separating brand from category personality", www.webuser.bus.umich.edu/plenk/brand\%20personality.pdf 19. 01.2006.

Beerli, A. \& Martin, J. D. (2004), "Factors influencing destination image", Annals of Tourism Research, vol: 31, no: 3; 657-681.

Cai, L. A. (2002), "Cooperative branding for rural destinations", Annals of Tourism Research, vol: 29, no: 3: 720-742.

Cohen, J. B., Fishbein, M. \& Athola, O. T. (1972), "The nature and uses of expectancy - value models in consumer attitude research", Journal of Marketing Research (pre-1986), Nov 1972; 9, 0004; 456 - 460.

Deslandes, D. D. (2003), Assessing Consumer Perception of Destinations: A Necessary First Step in the Destination Branding, The Florida State University College of Business, Submitted Dissertation of Doctor of Philosophy.

Diamantopoulos, A., Smith, G. \& Grime, I. (2005), "The impact of brand extentions on brand personality experimental evidence", European Journal of Marketing, 39: $1 / 2 ; 129-149$.

Eclipse (2003), "Destination image" Eclipse (the periodic publication from Moonshine Travel Marketing for destination marketer), edition 1: 4-5. www.moonshine.org

Gnoth, J. (2002), "Leveraging export brands through a tourism destination brand", Journal of Brand Management, 9; 4/5: 262 - 280.

Ha, C. L. (1998), "The theory of reasoned action applied to brand loyalty", Journal of Product and Brand Management, vol: 7, 1ss: 1; $51-57$.

Hall, J. (2004), “Branding Britain”, Journal of Vacation Marketing, 10, 2: 171 - 185. 
Hankinson, G. (2005), "Destination brand images: a business tourism perspective", The Journal of Services Marketing, 19: 1; 24 - 32.

Hayes, J. B. (1999), Antecedents and Consequences of Brand Personality, Submitted Doctoral Dissertation, Mississippi State University, Mississippi - U.S.A.

Henderson, P. W., Cote, J. A., Leong, S. M. \& Schmitt, B. (2003), "Building strong brands in Asia: selecting the visual components of image to maximize brand strenght", International Journal of Research in Marketing, 20 (2003): 297-313.

Hosany, S., Ekinci, Y. \& Uysal M. (2006), "Destination image and destination personality: An application of branding theories to tourism places", Journal of Business Research, 59 (2006): 638-642.

Jenkins, O. H. (1999), "Understanding and measuring tourist destination images", International Journal of Tourism Research, Jan/Feb 1999; 1 (1): 1-15.

Kar, G.H. \& Litvin S. W. (2003), "Destination image" Eclipse (the periodic publication from Moonshine Travel Marketing for destination marketer), Research Report, edition 1: 1-4.

Keller, K. L. (1993), "Conceptualizing, measuring and managing customer - based brand equity", Journal of Marketing, 57, 1: 1-21.

Kim, C. K., Han, D. \& Park, S. B. (2001), "The effect of brand personality and brand identification on brand loyalty: Applying the theory of social identification", Japanese Pyschological Research, vol: 43, no: 4; 195-206).

Kim, H. \& Richardson, S. L. (2003), "Motion picture impacts on destination images", Annals of Tourism Research, vol: 30, no: 1; $216-237$.

Leisen, B. (2001), "Image segmentation: the case of tourism destination", Journal of Services Marketing, 15 (1): 49-66.

Mackay, K. J. \& Fesenmaier, D. R. (1997), "Pictorial element of destination in image formation", Annals of Tourism Research, vol: 24, no: 3; $537-565$.

Morgan, N. J., Pritchard, A. \& Piggott, R. (2003), "Destination branding and the role of the stakeholders: The case of New Zeland", Journal of Vacation Marketing, Jun 2003; 9; 3; 285-299.

Özmen, E. (2004), The Effect of Country - of - Origin on Brand Image: The Case of Mavi Jeans - A Turkish Brand in the U.S., Submitted MA Thesis, California State University, U.S.A.

Plummer, J. T. (1985), "How personality makes a difference", Journal of Advertising Research, 24 (6): 27 - 31.

Prebensen, N. K. (2006), "Exploring tourists' images of a distant destinaiton", Tourism Management, article in press.

Simoes, C. \& Dibb, S. (2001), "Rethinking the brand concept: new brand orientation", Corporate Communications: An International Journal, vol: 6, no: 4; 217 - 224.

Sirakaya, E. \& Woodside, A. G. (2005), "Building and testing theories of decision making by travellers", Tourism Management, 26 (2005): 815-832.

Wee, T. T. T. (2004), "Extending human personality to brands: the stability factor", Journal of Brand Management, Apr. 2004; 11, 4: 317-330.

White, C. F. (2004), "Destination image: to see or not to see", Internaional Journal of Contemporary Hospitality Management, 2004; 16, 4/5, pg: 309-314.

World Travel \& Tourism Council (2003), Turkey: The Impact of Travel \& Tourism on Jobs and the Economy, WTTC, United Kingdom, www.wttc.org

Wysong, S., Munch, J. and Kleiser, S. (2002), "An investigation into the brand personality construct, its antecedents and its consequences", American Marketing Association Conference Proceedings, 2002 (13): 512-518. 